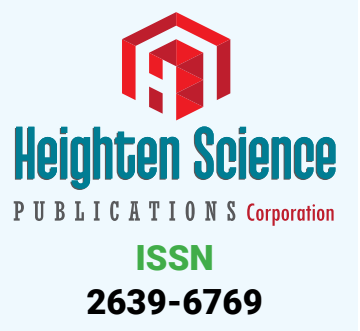

*Address for Correspondence: Ramaz Shengelia Department of the History of Medicine and Bioethics, Tbilisi State Medical University, Georgia, Tel: +995 599 565660; Email: shengelia@tsmu.edu

Submitted: 27 December 2016

Approved: 18 January 2017

Published: 20 January 2017

Copyright: @ 2017 Shengelia R, et al. This is an open access article distributed under the Creative Commons Attribution License, which permits unrestricted use, distribution, and reproduction in any medium, provided the original work is properly cited.

\section{Ethical Dimensions of Population Genetic Research in the Caucasus}

\author{
Ramaz Shengelia ${ }^{1 *}$ and Theodore G Schurr ${ }^{2}$ \\ 'Department of the History of Medicine and Bioethics Tbilisi State Medical University, Georgia \\ ${ }^{2}$ Department of Anthropology University of Pennsylvania, USA
}

\section{ABSTRACT}

The emergence and establishment of anthropological genetics as an interdisciplinary science is primarily, associated with the development of new genomic technologies. Precision genetic testing on the one hand, and the rapidly increasing number of genetic investigations on the other, have created a set of bioethical dilemmas for genetic and epidemiology research. Such research deals with persons who have the right to the protection of their personal information and confidentiality, and also concerns collective (village, region, ethnic group, state) consciousness, ethnic identity, and traditional culture, i.e., so called "ethnic pride". In this regard, taking into consideration the results of ongoing field research, we make some recommendations for better management of relationships with individuals and communities and the preparation of questionnaires and informed consent forms that will facilitate similar research projects, especially in such an ethnically, linguistically and culturally diverse region such as the Caucasus.

\section{THE CAUCASUS AS THE FOCUS OF GENETIC RESEARCH}

Irrespective of its small territory, the Caucasus is an extremely diverse region in all aspects, whether climatic zones, soils, landscapes, flora, fauna and most certainly human populations [1]. In this region, people speak up to 60 different languages and belong to the same number of nations and ethnic groups (Peoples of the World, Peoples of Caucasus. II. M. 1962) [2]. Relationships between these nations, ethnic and sub-ethnic groups are non-uniform in time and space. Many of this populations we can not consider as "nation", because of , at least, very small quantity, not independent history, language similarity with neighbors etc. In anthropological terms, one can view the peoples of the region to share a common "Caucasian origin", although this may not be evident at the political level. Due to certain internal and external forces, there are many cases of political confrontations and some of them are intended for national disintegration processes in a long run. On the other hand, the existence of the Caucasus as a unified political conglomerate, in the Bronze and early Antique ages is not confirmed by any reliable evidence [3], although one can observe similarities of archeological cultures [46], ethnological materials, and myths and beliefs in different regions of Caucasus which suggest a common origin for Caucasian peoples [7]. This view is further supported by a historical tradition maintained by Georgian and Armenian sources ( $8^{\text {th }}-11^{\text {th }}$ centuries) about the brotherhood of Caucasian ethnarches, their origination from the same family [8]. Many of authors are giving special importance to this paradigm.

Since the late Antique period, Georgia was the initiator of the cultural and political unity of the Caucasus, given that it was the only state recognizing one of the orthodox Abrahamic religions with its own alphabet and legitimate royal dynasty [3]. In that period, in the North Caucasus, although not fully explained, the Scythians came into the control, leading to the creation of astate in the Hellenic period [9]. In the early 
Medievalperiod, the Khazars appeared and became a quite powerful Khanate. At approximately the same period, Ossetia was recognized as a powerful state and community of Kipchaks [10]. Even during the flourishing of the Georgia kingdom, it is impossible to regard the Caucasus as a unified political and cultural entity, as in the period of closest relations the Caucasus could be regarded as a political confederation. Here, we will not discuss the state of Armenia, its alphabet and royal dynasties [11], as its geographical location and not quite successful political activity during that period did not allow it to become a unifying factor for nations located on both sides of Caucasus Mountain Range. Only Georgia, being in the center of these processes, could undertake this role and it has done this more or less successfully.

A deep disintegration of the Caucasus began with attacks of the Mongols in the $12^{\text {th }}$ century, continued with numerous attacks of Tamerlane and his long stay in the North Caucasus, and was propagated through the spread of Islam there. As a consequence, during that period, the Georgian kingdom became weaker and these processes became irreversible. In the North Caucasus, Islam has never become powerful, and together with local traditions it developed into something of a syncretistic religion [12].

The entry of Russia into the region in the $18^{\text {th }}$ century dramatically changed the situation. To protect themselves from this aggressive Christian state, North Caucasians used Islam to consolidate power and gain support from the Ottoman Empire. Through these actions, whether intentional or not, they came into direct confrontation with their southern neighbor-Christian Georgia. This situation was particularly painful when the Russians restricted their access to the southern steppes and redirected this unpredictable power to the south. Russian empire has not only supported disintegration processes among the Caucasian peoples but also regarded this goal as one of its significant political priorities. This strategy was the only way to break the will of the indomitable Caucasian peoples and taking full control over the region [12].

Accordingly, this policy created significant problems for the numerous sub-ethnic groups in Georgia and caused protests from the side of Georgian political and cultural elite [10]. These sub-ethnic groups have always regarding themselves as Georgians, and the desire of the new suzerains to divide them and recreate them as different nations was fiercely resisted [10]. It is interesting that similar attempts have never stopped and appear in different forms. This could be said about inadequate, biased interpretations of the results of population genetic research, as well.

The Caucasus, in the view of world's educated or even less informed people is perceived non-uniformly- it is seen as both united and kaleidoscopically diverse at the same time. Thus, Caucasian particularism can be seen, to different extents, not only at the ethnic and sub-ethnic levels but also at the micro-regional and frequently at the "lands" level [5].

These observations raise a question: Irrespective of the above language, cultural and ethnological similarities and differences, is there a serious reason to conceive of a common Caucasian source population (that is, a place and time in which a common Caucasian genetic pool arose?)

Caucasus populations have attracted the interest of numerous scientists, who have conducted numerous genetic studies in the region [13-16]. However, to date, due to certain (political instability in the region, financial problems, etc.) reasons, these studies have not been systematically undertaken across the region. These studies have contributed to an emerging picture of mitochondrial DNA (mtDNA), Y-chromosome and autosomal genetic diversity in Caucasus populations. Based on these studies, Caucasus populations are quite genetically diverse, with contrasting patterns of mtDNA and Y-chromosome diversity appearing in them, probably due to the effects of genetic drift and social organization in different ethnic groups. 
Such data have raised intriguing questions about the source of the genetic diversity in the region. One possibility is that the Caucasus has served as a genetic sink to which population expansions from different regions over many thousands of years have contributed to the genetic diversity that is currently observed there. Alternatively, the Caucasus may have been a reservoir of genetic diversity from which different genetic lineages emerged, in part due to the role of Caucasian mountains is shaping population distributions and interactions in the region.

Previous work also has suggested that genetic variation has been structured by the linguistic diversity of the North Caucasus [17] and that the Caucasus region has been an impassable barrier for migration and interactions between the peoples of the region [18]. Such results require further reflection on models of the population history of the Caucasus, and have stimulated additional population genetic research into the biological relationships between the peoples of the region.

The answers to these key questions should be provided by anthropological genetics and bio-archeology. The genetic study of Caucasian populations is of great interest in many respects -scientifically, culturally, linguistically and politically. Today, the Caucasus is divided into two parts - South and North. While some people desire to legalize this division and others desire freedom from it, one wonders what these attitudes would be once new genetic and anthropological data are brought into public consciousness.

\section{THE GENETIC HISTORY OF GEORGIA PROJECT}

This project is of great interest with respect to scientific and cultural studies. It provides new population genetic data from contemporary Georgian populations living in the specific territories for many generations and that have not been subject to genetic studies in the past. This research will contribute to knowledge about the histories of the participant ethnic groups, as well as identify the scale of inter-regional population's dynamics within Georgia.

In addition, comparison of genetic diversity in Georgia with that of the entire Caucasian region [14,19-22] will contribute to an expanded assessment of the bio-cultural versatility of the entire Near East. Thus, this project will improve our understanding of the bio-cultural impact of prehistoric migrations since the Paleolithic $[23,24]$ and Neolithic dispersals that took place between 4000 and $2000 \mathrm{BC}$ [25].

Moreover, this project will be beneficial for both Georgian and American participants. In an academic respect, this project will contribute to the strengthening of international scientific collaboration between the University of Pennsylvania and Georgian academic institutions. Significant joint scientific reports will be produced and published in a form of articles in peer-reviewed magazines and presented at scientific forums.

As part of this anthropological genetics project, we conducted expeditions in the high mountain region of Georgia-in Zemo Svaneti in 2012 and in the highlands and lowlands of Samegrelo in 2016. In Svaneti, 200 individuals and in Samegrelo 500 individuals were enrolled in the study. These represent quite large samples, considering that the total population of Svaneti is 12,000 and that of Samegrelo 700,000. Furthermore, these expeditions covered almost all large communities and great majority of the families living there. The results of the work in Svaneti are published or under review [26] and the analysis of the samples from Samegrelo will be completed shortly.

Normally, DNA samples are collected through buccal swabs, a sampling process that is associated with minimal risk. This approach follows the theoretical principles of recognized bioethics standards $[27,28]$, the practical regulations provided by the 
University of Pennsylvania IRB, and the guidelines established by Georgian legislation and National Committee of Bioethics of Georgia [29-31].

- Confidentiality is ensured by the following rulesRecords on paper are stored in safe place and only project researchers have access to them.

- Computer files summarize genealogical and genetic data are available to the project personnel only, subject to special access codes. Before getting familiarized with any information related to the project, study personnel shall sign the application on ensuring safety and confidentiality of the identification information. Identifying information shall be removed from the research data as much as possible.

- We regard that online interviews are inappropriate for the project, as proper security measures cannot be fully ensured.

- Audio and/or video records will be copied and securely maintained after the duration of the project in order to preserve them as oral histories of participants and their communities.

With respect to privacy, genetic data from the sample analysis will be maintained electronically under password protection in the computers of co-participant laboratory managers. The use of all genetic data in statistical and phylogenic analysis will be done with anonym zed identifiers. With the exclusion of the scientific manager, co-manager and laboratory personnel directly engaged in the genetic analysis process, no one else will have access to information that allows identification of the participants with specific DNA samples. Any hard copies of this kind of information will be stored in the locked cabinets.

Similarly, all genealogical data collected in the process of sampling will be stored in the laptops kept in the laboratories of the scientific managers, locked in their offices. They are available to the lab personnel directly participating in the project. Photos and archival materials potentially containing identifying data will also be stored in the secure computers.

If female participants desire that their samples be taken by female study personnel, then this condition will be complied with.

Before commencement of the DNA sampling procedure, for inclusion of the participants in the research, informed consent forms written in Georgian language will be used. Given that the literacy levels of participants may differ, members of the research team who are people fluent in Georgian, Svanetian, Megrelian or, if required, Russian, will provide assistance to the participants by translating the details of the informed consent forms.

American and Georgian personnel involved in the project will be trained in human subject's protocols before taking DNA samples, collecting genealogical data and obtaining informed consent.

In the process of conducting fieldwork, we identified certain difficulties and questions that, in our opinion, are common for research in general and those in similar circumstances in particular. These problems were basically associated with the development of informed consent forms and questionnaires, the interview format, and the explanation of the project where the researcher verbally communicated the details of the study to potential participants.

Potential participants, irrespective of their ethnicity and religion, in being the subjects of research, are more or less similar in their views of themselves. In discussing cosmogony and ethnic genetic issues with them, we noted that: 
- Almost all Caucasians, whether representatives of relatively widespread ethnic or sub-ethnic groups, in the historical perspective, regard themselves as a people of unique origin;

- They look to other people, especially those who are not of Caucasian origin, with a certain sense of superiority although they express particular respect for them and are ready to tolerate almost everything from them when they are guests;

- Caucasians, given their current social and political vulnerability, have an especially keen instinct of self-preservation and attempt to prevent any violence and deception against them; therefore, irrespective of the statement in the previous section, they lack trust in foreign researchers.

For these reasons, the inclusion of local administration, elders and simply respected persons of the local community is essential to gaining the trust of participants and, if required it, answers from researchers about the project. In general, this attitude is more frequently expressed by older individuals. The attitude of younger people differs with respect to participation in research projects, and they are mostly oriented towards compliance with legal requirements.

\section{In addition, it should be noted that:}

- Most respondents do not closely read the informed consent form and they prefer to trust the known and respected person- whether local or visitor. If required, they will demand answers from them and quite strictly so. This attitude contains certain risks. They may also listen to oral explanations and continue communication based on the principle of trust."

- Part of the population may have certain relations with criminals, especially in regions where revenge is a tradition. As a result, they are reluctant to participate in research projects. However, if they agree, the responsibility is shifted from the law enforcement authorities to the researchers and/or those who supported the researchers and so called "mediators".

Regarding all of the above, we found a simple solution. In all villages and communities, we met with the potential participants and offered quite lengthy interactive explanations, clarifying all disagreements and answering all questions. Irrespective of these measures, about $8-10 \%$ of attendants chose not to participate and left the meetings. The main cause for their departure was distrust of the study.

As mentioned, the secondary problems dealt with the test results and their possible interpretation, and surprisingly this was not associated with the education and awareness of the participants.

Other potential issues with anthropological genetic research in the Caucasus should be recognized. These included the results of specific tests and level of generalization in the scientific work; the openness of the personal, family and higher level relations' genetic data; the adequacy of the conclusions and their correctness; the correspondence and expected differences of genetic data with the traditional historical and cultural paradigms; and participants satisfaction with this the DNA results, which may range from disappointment to mental pain, and sometimes expressed in aggression.

Each of the above issues should be considered generally but very carefully in advance of discussions of the research with communities and further refined, if required, at the time of face-to-face communication with participants. The relatively educated members of the community are the carriers and keepers of correct information, and are persons whom the other community members trust. Thus, working with them requires a particular responsibility on the part of the researchers. 
In addition to the certificates sent to the participants upon completion of the DNA analysis, which explain the genetic results including their haplo group background, we recommend reporting the results of the study directly to the participating communities. As an example, we reported the outcomes of 2012 expedition in Svaneti publicly in 2015 in Mestia (the administrative center of Zemo Svaneti) during a Caucasus history conference. Our explanation of the findings was very satisfactory to members of the Svan population. Based on our experience, this is a very reasonable step, and one that we regard as a necessary component of the population genetic research design. Such communication respects the desire of certain part of the population to participate in the research and allows them to learn about the research findings firsthand from project researchers, who provide them with actual scientific interpretations. In addition, this is a mechanism for assuring adequate ethical oversight of the project in relation to study populations, and helps to minimize the potential complications mentioned above.

Unfortunately, recently, in social networks and, surprisingly, in the popular and scientific literature, there are unproductive discussions of false interpretation of population and bio-archeological research. Genetic lineages with ages of tens of thousands years are frequently identified with one of the nations or ethnic groups, and the time of linguistic and cultural formation of currently existing nations can supposed be found in the visible and materially verifiable past [32].

The search for scientific arguments that justify political goals and "genetic patriotism" goes beyond the anthropological exploration of population histories. Stories about genetically belonging to an outstanding people, certain families, nations, etc., are published, and these actions are followed by the fantastic interpretations providing fertile soil for the false patriotism, xenophobia and aggression. Thus, a primary step towards mitigating the misuse of genetic information is commencement of scientifically grounded genetic studies conducted with full participation of different Caucasian communities. This approach will contribute to the generation of guidelines for human subject's research in the Caucasus, and open opportunities for coordinated and collaborative research in this area.

\section{REFERENCES}

1. Tbilisi. Georgian Soviet Encyclopaedia (GSE). Vol. V; VIII. 1975-1987.

2. Народы Мира. Народы Кавказа т. World Nations. Caucasian Nations. Vol. II. pp. 37. 1962.

3. Javakhishvili I. Tbilisi. Txzulebani. Works.Vol. I. Tbilisi. 1982.

4. Didebulidze, Z.M. Культурная Взаимосвязь народов Грузии и Центрального Кавкааз в 10 -12 векаx [Cultural Interconnections of the Peoples of Georgia and Central Caucasus in the $10^{\text {th }}-12^{\text {th }}$ Centuries]. Tbilisi. 1983.

5. Ithonishvili V, Caucasus and Caucasians (Historical and Ethnographical Manual), Tb, pp. 30-34; 47-48. 2007.

6. Ethnicities in Georgia, Tb. pp. 129-132. 2008.

7. Materials for the Ethnography of Georgia. (MEG), Vol's. 1-24. 1939-90. Tbilisi. masalebisaqarTveloseTnografiisTvis (mse)t. 1-24 1939-1990.

8. Qartlis Cxovreba, Vol. I, Tb, pp. 126. 1955.

9. Latyshev VV. Data of the Ancient Writers about Scythia and Caucasus, v. СПБ. pp. 239. 1890

10. Tbilisi. Issues on History of Georgia (IHG). saqarTvelos istoriis narkvevebi (sin), Vol. II-III-VII. 19771982.

11. Chahin, M. The Kingdom of Armenia. Reprint: Dorset Press, New York. 1987

12. Бурнашев С. Д. Описание горских народов, Курск. 1794.

13. Barbujani G, Nasidze I, Whitehead GN. Genetic Diversity in the Caucasus. Human Biology. 1994; 66: 639-668. Ref.: https://goo.gl/8pLhoc 
14. Nasidze I, Salamatina NM. Genetic characteristics of the Georgian population. Gene Geography. 1996; 10: 105-112.Ref.: https://goo.gl/wqhgeD

15. Bulayeva KB, Jorde LB, Ostler C, Watkins S. Genetics and population history of Caucasus populations. Human Biology. 2003; 75: 837-853. Ref.: https://goo.gl/fyU4JL

16. Rootsi S, Myres NM, Lin AA, Järve M, King RJ, et al. Distinguishing the co-Ancestries of Haplogroup $\mathrm{G}$ Y-chromosomes in the Populations of Europe and the Caucasus. European Journal of Human Genetics. 2012; 20: 1275-1282. Ref.: https://goo.gl/F9J1sz

17. Balanovsky O, Dibirova K, Dybo A, Mudrak O, Frolova S. et al. Parallel Evolution of Genes and Languages in the Caucasus region. Molecular Biological Evolution. 2011; 28: 2905-2920. Ref.: https://goo.gl/kv4nOH

18. Yunusbaev B, Metspalu M, Järve M, Kutuev I, Rootsi S, et al. The Caucasus as an asymmetric semipermeable barrier to ancient human migrations. Molecular Biology and Evolution. 2012; 29 359-365.Ref.: https://goo.gl/QxhfZI

19. Comas D, Francesc Calafell, Eva Mateu, Anna Pérez-Lezaun, Elena Bosch, et al. "Trading genes along the Silk Road: mtDNA sequences and the origins of Central Asian populations. American Journal of Human Genetics. 1998; 63:1824-1838. Ref.: https://goo.gl/Wt6LZg

20. Di Benedetto G, Ergüven A, Stenico M, Castrì L, Bertorelle G, et al. "DNA Diversity and Population Admixture in Anatolia". Am J Phys Anthropol. 2001; 115: 144-156. Ref.: https://goo.gl/sPQWsO

21. Nasidze I, Ling EY, Quinque D, Dupanloup I, Cordaux R, et al. Mitochondrial DNA and Y-chromosome Variation in the Caucasus. Annals of Human Genetics. 2004; 68:205-221. Ref.: https://goo.gl/ EjXBVz

22. Perez-Lezaun R, Calafell F, Comas D, Mateu E, Bosch E, et al. Sex-Specific Migration Patterns in Central Asian Populations, Revealed by the Analysis of Y-Chromosome Short Tandem Repeats and mtDNA. American Journal of Human Genetics. 1999; 65: 208-219. Ref.: https://goo.gl/3a5RZU

23. Adler DS, Bar Oz G, Belfer Cohen A, Bar Yosef O. Ahead of the game: Middle and Upper Palaeolithic Hunting Behaviors in the Southern Caucasus. Current Anthropology. 2006; 47: 89-118. Ref.: https:// goo.gl/Pwi4H5

24. Bruch AA. Temporal Corridors of Migration in the Southern Caucasus During the Late Early Pleistocene. Quaternary International. 2012; 279-280: 72-73.

25. Algaze G. The Uruk Expansion: The Dynamics of Expansion of Early Mesopotamian Civilization. Chicago: University of Chicago Press. 1993.

26. Schurr TG, YardumianA, Shengelia R, Bitadze L, Chitanava D, et al. GeneticDiversity and PopulationHistory in Svaneti, Northwestern Georgia. "CaucasianCivilization: Interdisciplinaryresearch", Mestia-Tbilisi, Georgia. 2015.

27. Beauchamp TL, Childress J. Principles of Biomedical Ethics: New York: Oxford University Press. 2006.

28. Mamulashvili B. Bioethics in Cultural Values. Tbilisi.mamulaSvili b. bioeTikakulturulRirebulebebSi. Tbilisi. 2006.

29. Javashvili G, Kiknadze G, Barkalaia A. GeorgianLegislation on Human rights in the Sphere of Biomedicine, Tbilisi. 2001.

30. Shengelia R. Sanikidze E. Biomedical Ethics. Tbilisi. 2011.

31. Sengelia R, sanikiZe E, Tbilisi. Ethical Problems of Clinical Practice and Biomedical Research. klinikuri praqtikisa da biosamedicino kvlevebis eTikuri problemebi. 2013.

32. Klyosov AA, Penzev KA. The Aryan Peoples in the Vastness of Eurasia. 2015.

33. L.Melikishvili. Ethnical Aspects of Social Security in Multiethnical Society. 2011; 46, 47, 58. 